\title{
Comprehensive use of waste after benificiation of magnetite fraction by floatation
}

\author{
Nikolay Afanasievich Shapovalov \\ Belgorod State Technological University named after V. G. \\ Shukhov \\ The Department of theoretical and applied chemistry \\ Belgorod, Russia
}

Lilia Khasanovna Zagorodnyuk

Belgorod State Technological University named after V. G. Shukhov

The department of construction material science, components and design

Belgorod, Russia

\author{
Andrey Ivanovich Gorodov \\ Belgorod State Technological University named after V. G. \\ Shukhov \\ The Department of theoretical and applied chemistry \\ Belgorod, Russia
}

\author{
Anastasiya Yurievna Shekina \\ Belgorod State Technological University named after V. G. \\ Shukhov \\ The department of construction material science, \\ components and design \\ Belgorod, Russia
}

\author{
Anatoly Anatolyevich Krainiy. \\ Belgorod State Technological University named after V. G. Shukhov \\ The Department of theoretical and applied chemistry \\ Belgorod, Russia
}

\begin{abstract}
The article deals with finding the optimal floatation conditions for the final tailings of wet magnetic separation. To solve the problem, several laboratory tests were made using a floatation machine, which helped to determine the needed reagent composition, temperature and time of reverse cationic floatation. The home-produced FLON and foreign-made PA-14 reagents proved to be the most effective collectors for the final tailings of Mikhailovsky mining and processing plant. Hydrolyzed starch was found to be the most active depressor. The recommended concentrations of the collector and the depressor are $250 \mathrm{gram} / \mathrm{ton}$ and $500 \mathrm{gram} / \mathrm{ton}$, correspondingly. The rebeneficiation of wet magnetic separation waste containing $32 \%$ of iron and $60 \%$ of silicon resulted in obtaining a concentrated product including $61 \%$ of iron and $16 \%$ of silicon expressed as oxide. The concentrate yield is $26 \%$ of the initial load mass. The work also establishes the procedure for using the waste of iron ore beneficiation as a mineral filler for the composite binding materials.
\end{abstract}

Keywords - floatation; float reagent; tailings; composite binding materials.

\section{INTRODUCTION}

The extraction of jaspilites results in a considerable ecological impact, both in Russia and abroad. This is due to their beneficiation process when a huge amount of ore and gangue gets into tailing dumps or refuse disposal as waste. Some types of iron ore are only stored and not processed at all. These are primarily oxidized jaspilites, which cannot be efficiently processed nowadays because of lack of technology [1-3].

The jaspilite rebenificiation by floation (after magnetic separation) increases the yield of saleable products (ferrous oxides), but also raises the ecological impact, as floatation technology uses nitrogenous cationic surfactants which adsorb onto floatation waste and get into tailing dumps together with process water. These surfactants further go through biological and chemical transformation. They partially desorb and penetrate aquifers and surface waters. This is aggravated by the fact that many foreign float reagents do not possess ecotoxicological characteristics [4-6].

The comprehensive processing of iron ore is the most efficient and cost-effective. This involves rebeneficiation by floatation of unoxidized jaspillites as well as beneficiation by floatation of by-produced acidized jaspillites, generally represented by hematite.

Unoxidized jaspilites of Mikhailovskoye ore deposit are of complex material composition with high chemical, physical and mechanical heterogeneity. These are very hard ores with thin inclusions of minerals. The technology of lean hematite and magnetite ores processing includes breaking, reduction, and five-stage wet magnetic separation. The last uses a weak field and separates dump tales at every stage. Iron ore containing 35-40\% can be processed into the concentrate with 65-66 \% Fе и 7-8 \% $\mathrm{SiO}_{2}$ content, whereas tailings hold 24$26 \%$ of iron.

This separation scheme cannot be used with a wide range of low-magnetic iron-containing materials in unoxidized jaspillites of Mikhailovskoye ore deposit. This leads to a considerable metal loss.

The main losses are due to the presence of hematite, which passes into tailings together with silicates, carbonates and insignificant amount of magnetite. The number of tailings produced per year is 16,2 million tons. The tailing dump is growing in both square and volume influencing negatively the 
environment. Different environmental measures cannot fully prevent its dusting.

It is possible to increase the yield of saleable products and decrease the negative environmental influence by using the floatation tailing processing and rebenificiation by floatation of magnetite fraction.

In this respect, the reverse cationic floatation is the most perspective method that can significantly decrease the amount of silicone oxide and other gangue components contained in the produced iron-containing concentrate.

\section{Methodology}

This work uses the reverse cationic floatation method for rebenificiation of tailings. The laboratory tests were done using FM-3 floatation machine with automatic adjustment of the impeller speed, air supply, slurry temperature and skimming speed. Infrared spectroscopy was used to identify nitrogenous cationic surfactants (amines, diamines, amine and diamine ethers). An extraction-photometric method was used to determine the concentration of nitrogenous cationic surfactants in the solution. A gravimetric method was applied to calculate the mass fraction of free silicon oxide. ARL 9900 WorkStation with in-build diffraction system was used for comprehensive chemical and mineralogical analysis. The grain-size composition was identified by means of laser grain sizing on Microsizer 201C. The TESCAN MIRA 3 LMU scaning-electron microscope with $\mathrm{x}$-ray emission microprobe was used for analytical analysis of hydrated cement samples. The processes and products of cement hydratation were examined with help of DRON-3 X-ray diffractometer. All the tests with cements were done according to the state standards.

\section{MAIN PART}

The laboratory tests were done using FM-3 floatation machine with automatic adjustment of the impeller speed, air supply, slurry temperature and skimming speed. During the experiments water was poured into the floatation cell taking about $50-80 \%$ of the cell volume. The impeller was then turned on and the ore charge was loaded gradually. Next, the reagents were added in the following order: $\mathrm{pH}$ environment regulator (caustic soda), depressor (hydrolyzed starch) and cationic collecter. The suspension was mixed for two minutes after adding each reagent and then air was supplied to the cell. The process of skimming stopped after 5-6 min. due to froth absence or its insufficient charge.

The control floatation was carried out after skimming. To do that the air supply was turned off and reagents were additionally measured. The suspension was then mixed for two minutes after which the air supply was turned on again. The control floatation finished with the operation of skimming and the floatation concentrate was unloaded from the cell.

Froth pulp was added to the cell during the process of recleaning. The first recleaning was done with the help of a depressor, which resulted in the middling product and the froth product, which was recleaned several times. The number of recleanings was determined by experimental methods. Floatation products were settled, clear water was decanted and wet settlings were dried in a drying box.

The described floatation process is represented in Fig.1. The amount of iron and silicon oxides in the source stock (floatation feed), cell product (concentrate) and floatation tailings (froth pulp) was also controlled.

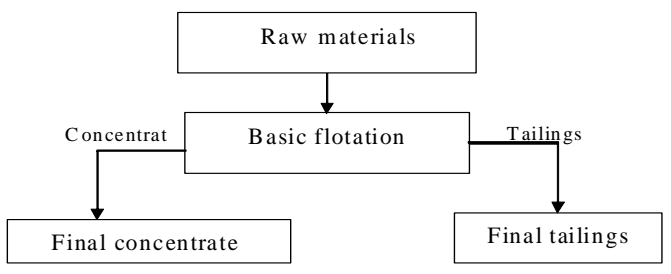

Fig. 1. The scheme of beneficiation by floatation of hematite quarzite in a laboratory setting.

Cationic collectors were acidified by $30 \%$ before floatation using $10 \%$ acetic acid solution [6]. Collector concentration changed in the range from 50 to 350 gram/ton. The depressor concentration (hydrolyzed starch) was 300 gram/ton. The results of the experiments are shown in Fig.2 and Fig.3. They indicate that tallow polyoxyethylene amines and octylamine acetate, offered as collecters, showed low floatation activity and their further usage is not worthwhile. Dodecylamine acetate showed a good result. However, it is inferior to the home-produced FLON and foreign-made PA-14 reagents. The nomographic charts represent the amount of iron and silicon oxides in concentrations depending on which collector (FLON or PA-14) is used (Fig.4).

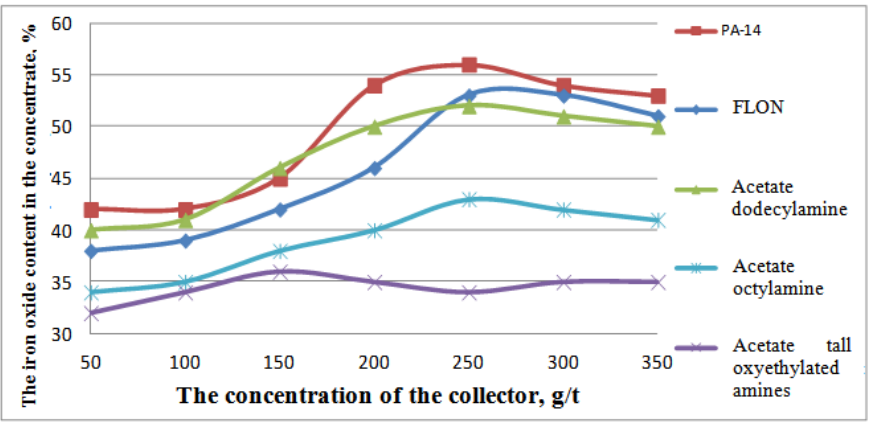

Fig. 2. The amount of $\mathrm{Fe}_{2} \mathrm{O}_{3}$ in the cell product depending on the collector concentration.

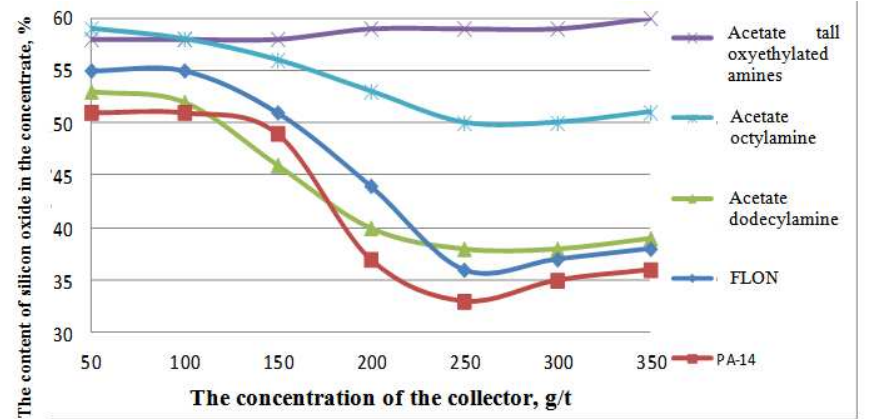

Fig. 3. The amount of $\mathrm{SiO}_{2}$ in the cell product depending on the collector concentration. 
The analysis of collector concentration influence on tailings floatation (Fig.2 and 3) shows that the optimal collector concentration is 250 gram/ton, because floatation indicators (the amount of $\mathrm{Fe}_{2} \mathrm{O}_{3}$ and $\mathrm{SiO}_{2}$ in the concentrate) take the best values with this concentration.

Dodecylamine acetate and FLON float reagent showed good results as collectors, but they are slightly inferior to PA14 in terms of total iron and silicon expressed as oxides. At the same time, FLON collector has the maximum efficiency coefficient, considering both iron content and concentrate yield.

The activity of depressors that can hydrophilize mineral superficies, impeding air bubbles to stick to the surface of iron-bearing components was also researched [6]. The results are shown in Table.1. All the experiments had the same concentration of a depressor - 300 gram/ton and collector 250 gram/ton.

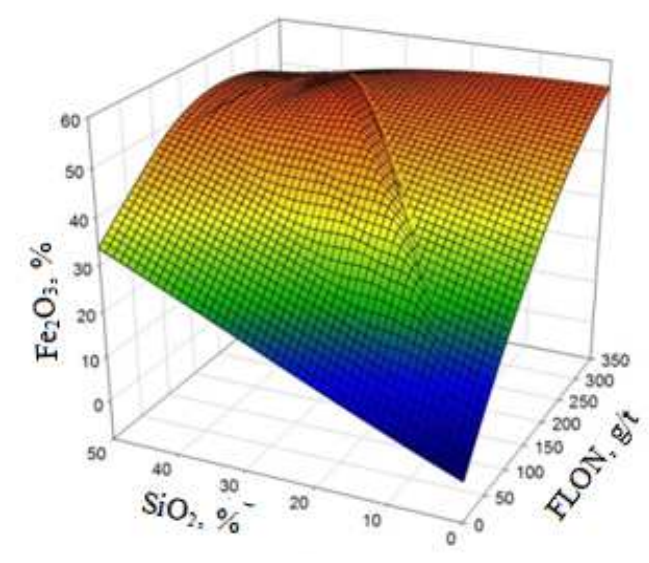

a)

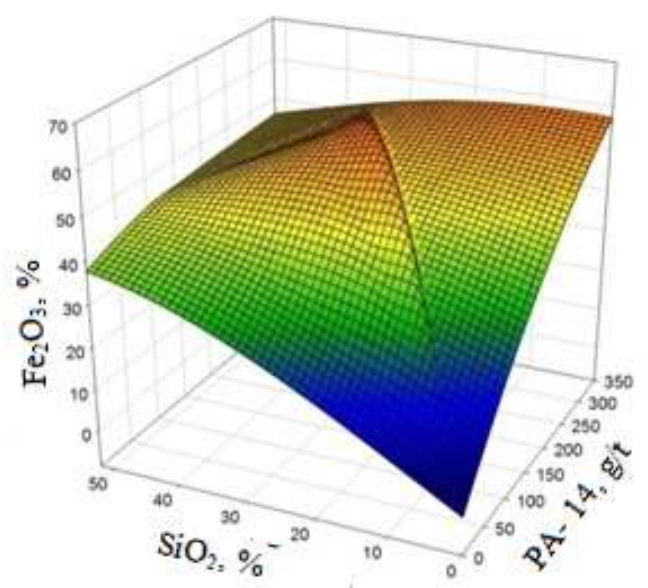

b)

Fig. 4. The amount of iron and silicon oxides depending on the concentration of float reagents: a) FLON, b) PA-14

As it is seen from the data in Table 1, hydrolyzed starch has the most depressive action towards iron oxide. On the other hand, C-3 reagents like rheotan, melment, neonol and tannin showed little activity. In this regard, the floatation with different concentrations of hydrolyzed starch was carried out (Fig.5). The nomographic chart shows the dependencies between the amount of iron and silicon oxides and the concentartion of the depressor in the presence of FLON and PA-14 collectors (Fig.6 a, b).

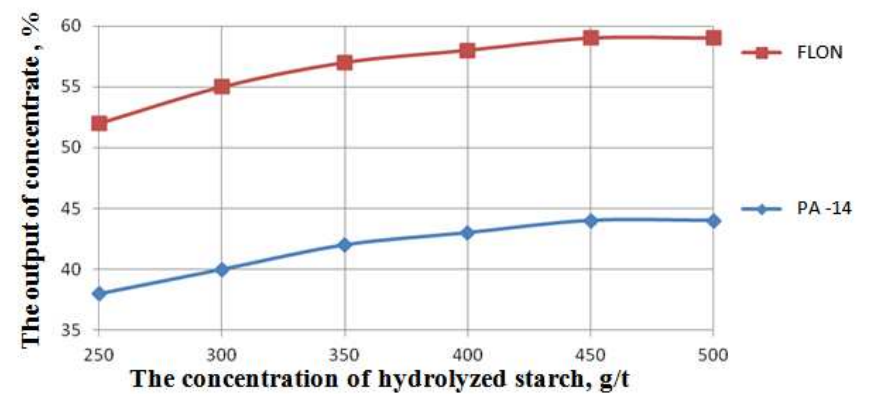

Fig. 5. The dependency between the concentrate yield and the depressor concentaration

The data in Fig. 6 show that an increase in the amount of hydrolyzed starch to 500 gram/ton leads to the rise of iron and silicon oxide percentage in the concentrate in both cases. It also worth mentioning that an increase in hydrolyzed starch concentration to 500 gram/ton results in the concentrate yield increase by 6-8 \% (Fig.5). Thus, the optimal concentration of starch for floatation with FLON is taken as 500 gram/ton. Iron ore concentrate contains a significant amount (more than 30 $\%$ ) of silicon oxides and cannot be considered a high-quality saleable product.

A control floatation of the concentrate must be added to the overall floatation process in order to obtain a high-quality product and to increase the percentage of recovered iron. Fig.7 shows the scheme of floatation in the laboratory setting that includes control floatation. Basing on the results of the previous experiments, the following concentrations of the components were taken: collector - 250 gram/ton, depressor 500 gram/ton. The amount of reagents loaded into the cell during control floatation was two times less basing on the recommendations of Mikhailovsky mining and processing plant. The results of the floatation can be seen in Table 2. It shows that FLON float reagent has the biggest efficiency coefficient after the control floatation.

The distribution of chemical elements (expressed as oxides) in the initial tailings and in the concentrates after the floatation with FLON and PA-14 is shown in Fig.8. 
TABLE 1 FLOATATION INDICATORS WITH DIFFERENT DEPRESSORS

\begin{tabular}{|c|c|c|c|c|c|c|c|c|c|c|}
\hline \multirow[t]{2}{*}{ № } & \multirow[t]{2}{*}{ Depressor } & \multirow[t]{2}{*}{ Collector } & \multirow{2}{*}{\begin{tabular}{|c|}
$\begin{array}{c}\text { Depressor } \\
\text { concentration, } \\
\text { gram/ton }\end{array}$ \\
\end{tabular}} & \multirow{2}{*}{$\begin{array}{l}\text { Concentrate } \\
\text { yield (cell } \\
\text { product), \% }\end{array}$} & \multicolumn{2}{|c|}{$\begin{array}{c}\text { The amount of oxides in } \\
\text { the concentrate, } \%\end{array}$} & \multirow{2}{*}{$\begin{array}{l}\text { Efficiency } \\
\text { coefficient }\end{array}$} & \multirow{2}{*}{$\begin{array}{l}\text { Froth pulp } \\
\text { yield, } \%\end{array}$} & \multicolumn{2}{|c|}{$\begin{array}{c}\text { The amount of } \\
\text { oxides in the froth pulp, \% }\end{array}$} \\
\hline & & & & & $\mathrm{Fe}_{2} \mathrm{O}_{3}$ & $\mathrm{SiO}_{2}$ total & & & $\mathrm{Fe}_{2} \mathrm{O}_{3}$ & $\mathrm{SiO}_{2}$ total \\
\hline \multirow{2}{*}{1} & \multirow{2}{*}{ Starch } & FLON & \multirow{2}{*}{300} & 56.00 & 53.00 & 36.00 & 0.82 & 44.00 & 26.00 & 67.00 \\
\hline & & PA-14 & & 40.00 & 56.00 & 33.00 & 0.68 & 60.00 & 24.00 & 68.00 \\
\hline \multirow{2}{*}{2} & \multirow{2}{*}{ Neonol* } & FLON & \multirow{2}{*}{1000} & 27.00 & 40.00 & 52.00 & 0.21 & 73.00 & 33.00 & 60.00 \\
\hline & & PA-14 & & 17.00 & 45.00 & 44.00 & 0.17 & 83.00 & 33.00 & 59.00 \\
\hline \multirow{2}{*}{3} & \multirow{2}{*}{ Tannin } & FLON & \multirow{2}{*}{300} & 15.00 & 40.00 & 51.00 & 0.12 & 85.00 & 31.00 & 61.00 \\
\hline & & PA-14 & & 42.00 & 43.00 & 41.00 & 0.44 & 58.00 & 35.00 & 59.00 \\
\hline \multirow{2}{*}{4} & \multirow{2}{*}{ C-3 } & FLON & \multirow{2}{*}{300} & 66.00 & 39.00 & 56.00 & 0.46 & 33.00 & 28.00 & 62.00 \\
\hline & & PA-14 & & 21.00 & 39.00 & 50.00 & 0.16 & 79.00 & 34.00 & 59.00 \\
\hline \multirow{2}{*}{5} & \multirow{2}{*}{ Reotan } & FLON & \multirow{2}{*}{300} & 19.00 & 41.00 & 45.00 & 0.17 & 81.00 & 31.00 & 61.00 \\
\hline & & PA-14 & & 41.00 & 41.00 & 50.00 & 0.34 & 59.00 & 35.00 & 58.00 \\
\hline \multirow{2}{*}{6} & \multirow{2}{*}{ Melment } & FLON & \multirow{2}{*}{300} & 28.00 & 40.00 & 55.00 & 0.20 & 72.00 & 29.00 & 60.00 \\
\hline & & PA-14 & & 67.00 & 44.00 & 49.00 & 0.60 & 33.00 & 31.00 & 61.00 \\
\hline
\end{tabular}

* - the floatation process does not take place with lesser ammounts

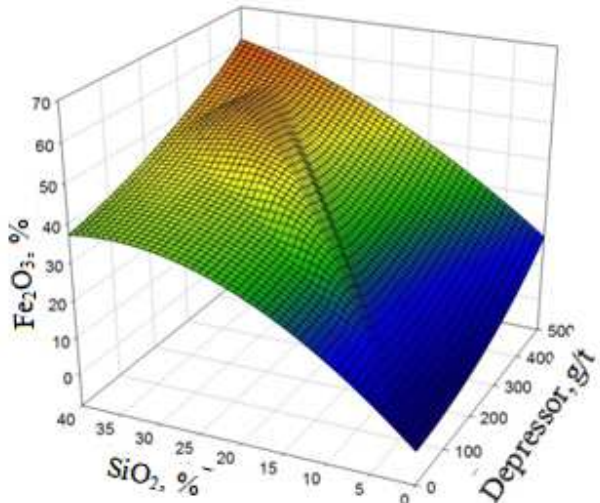

a)

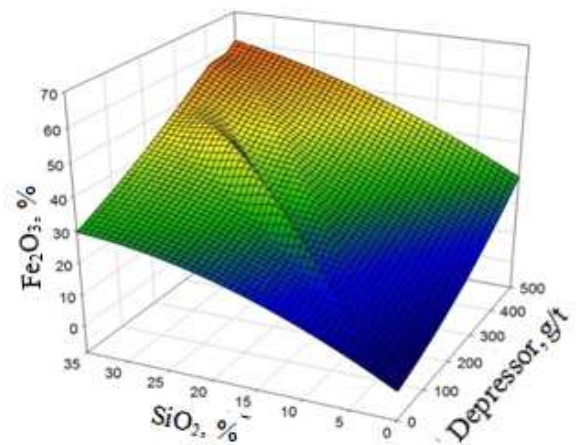

b)

Fig. 6. The dependency between the amount of silicon and iron oxides in the concentrate and the amount of a depressor a) collector - FLON, 250 gram/ton; b) collector - PA-14, 250 gram/ton

The beneficiation by floatation of tailings containing $32 \%$ of total iron and $60 \%$ of silicon oxide resulted in obtaining the iron-ore concentrate with $61 \%$ of total iron and $16 \%$ of silicon oxide.

The floatation results largely depend on the froth composition. That is why the coefficient of froth destruction and mineralization, the distribution of mineral particles sizes both in the concentrate and the froth and the overall specific surface of particles was identified when analyzing floatation products. These data indicate that the fine fraction passes to the froth when separated by floatation. The coarse fraction remains in the concentrate in both cases. However, more fine particles remain in the cell when using the FLON collector. This means it has better selectivity [6]

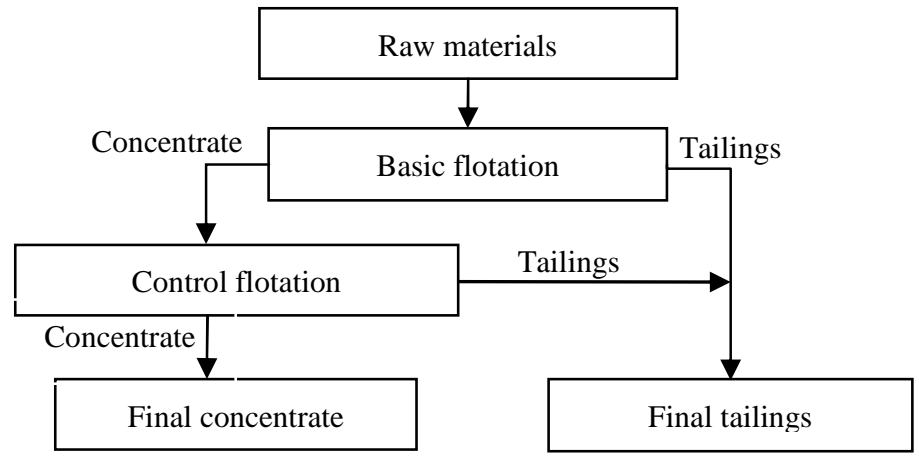

Fig. 7. The floatation scheme in the laboratory setting

TABLE 2. THE DATA OF BASIC AND CONTROL FLOATATIONS

\begin{tabular}{|c|c|c|c|c|c|c|c|c|c|}
\hline \multirow[t]{2}{*}{ № } & \multirow[t]{2}{*}{ Collector } & \multicolumn{2}{|c|}{$\begin{array}{c}\text { Collector } \\
\text { concentration, } \\
\text { gram/ton }\end{array}$} & \multicolumn{2}{|c|}{$\begin{array}{c}\text { Depressor } \\
\text { concentrati } \\
\text { on, } \\
\text { gram/ton } \\
\end{array}$} & \multirow{2}{*}{$\begin{array}{c}\text { Conce } \\
\text { ntrate } \\
\text { yield, } \\
\%\end{array}$} & \multicolumn{2}{|c|}{$\begin{array}{c}\text { Amount of } \\
\text { oxides in } \\
\text { concentrate, } \\
\% \\
\end{array}$} & \multirow[t]{2}{*}{ Efficiency } \\
\hline & & $\begin{array}{c}\text { Basic } \\
\text { flt. }\end{array}$ & $\begin{array}{c}\text { Control } \\
\text { flt. }\end{array}$ & $\begin{array}{l}\mathrm{Ba} \\
\text { sic } \\
\text { flt. }\end{array}$ & $\begin{array}{c}\text { Contro } \\
1 \mathrm{flt} .\end{array}$ & & $\mathrm{Fe}_{2} \mathrm{O}_{3}$ & $\begin{array}{l}\mathrm{SiO}_{2} \\
\text { total }\end{array}$ & \\
\hline 1 & FLON & \multirow{2}{*}{250} & \multirow{2}{*}{125} & \multirow{2}{*}{\begin{tabular}{|c|}
50 \\
0
\end{tabular}} & \multirow{2}{*}{250} & 26 & 61 & 16 & 0.99 \\
\hline 2 & PA-14 & & & & & 24 & 60 & 18 & 0.80 \\
\hline
\end{tabular}




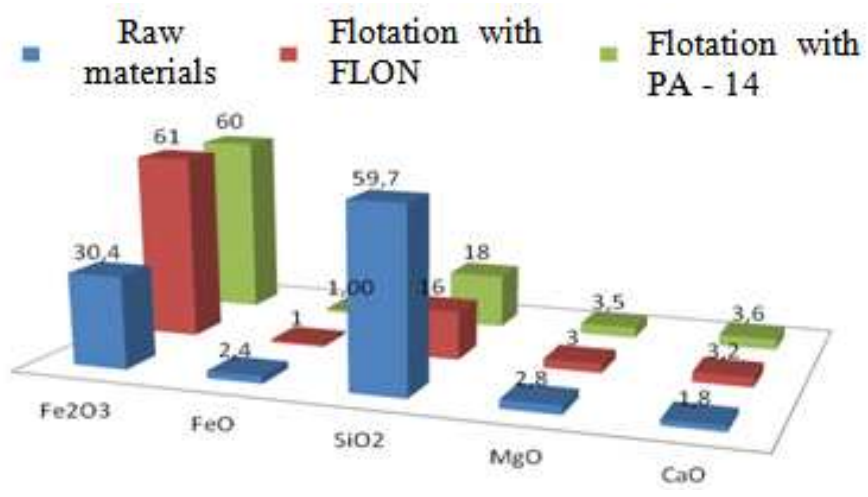

Fig. 8. The distribution of chemical elements (expressed as oxides) in the inititial tailings and the concentrate after the floatation with FLON and PA-14

The comprehensive analysis of the results indicates that FLON and PA-14 are the most effective floatation collectors for the tailings of Mikhailovsky mining and processing plant. The most effective depressor is hydrolyzed starch. The recommended concentrations for collectors and the depressor are $250 \mathrm{gram} / \mathrm{ton}$ and $500 \mathrm{gram} / \mathrm{ton}$, respectively.

The rebenificiation of wet magnetic separation waste containing $32 \%$ of total iron and $60 \%$ of silicon resulted in obtaining the concentrate having $61 \%$ of iron and $16 \%$ of silicon, expressed as oxide. The concentrate yield accounts for $26 \%$ of the initial load mass.

The rebenificiation of wet magnetic separation waste produces a by-product. It can be used as a filler for composite binding materials as part of a program for comprehensive separation waste use.

The waste produced after unoxidized jaspelite rebenificiation at Mikhailovsky mining and processing plant that gets into the tailing dump is characterized by high dispersion equal to $250 \mathrm{~m}^{2} / \mathrm{kg}$. The chemical analysis indicates that the waste contains more than $67 \%$ of silicon oxide and less than $26 \%$ of iron oxide. The content of other oxides found in scarce quantities makes it possible to use the waste as a mineral filler for composite binding materials [7-10].

The composite binding materials obtained in this research consist of CEM I 42,5H cement, which complies with GOST 31108-2003 state standard, and the waste of unoxidized jaspelite rebenificiation from Mikhailovsky mining and processing plant used as a filler.

The results of waste sizing with standard screens for inert material are shown in Table 3 .

TABLE 3. WASTE SIZING WITH STANDARD SCREENS

\begin{tabular}{|c|c|c|c|c|c|c|c|}
\hline \# screen & 2.5 & 1.25 & 0.63 & 0.315 & 0.16 & 0.08 & $\begin{array}{c}\text { less than } \\
0.08\end{array}$ \\
\hline $\begin{array}{c}\text { Remaining on } \\
\text { screen, \% }\end{array}$ & - & 0.42 & 7.62 & 12.36 & 26.70 & 52.10 & 0.80 \\
\hline
\end{tabular}

The saturated density of waste is $1460 \mathrm{~kg} / \mathrm{m}^{3}$. The analysis of grain-size composition of waste and cement was done by means of laser grain sizing (Fig.9).

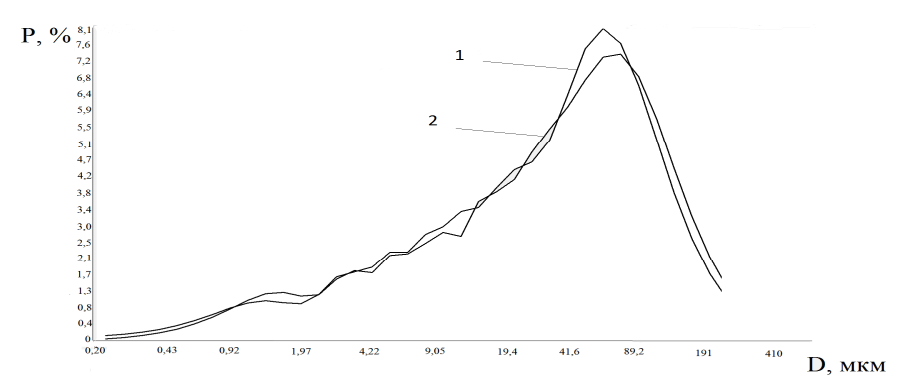

Fig. 9. Weight distribution of waste and cement particles by size: 1 cement, 2 - waste

In order to identify the optimal proportions of waste and cement in the material, the waste was added in different amounts in the range from 5 to $50 \%$, while the quantity of cement changed from 95 to $50 \%$ respectively. The combined raw mixture was reduced in a laboratory mill until the specific surface area of powder reached $300 \mathrm{~m}^{2} / \mathrm{kg}$. The analysis of physical and mechanical qualities of binding materials with different compositions was done on $30 \times 30 \times 30$ cube-shaped samples. Three samples for each composition were used for different test periods. The sample testing was done after 7 and 28 days of normal solidifying.

The limit of compressive strength of the obtained binding materials (Fig.10) is higher than the compression strength of the cement. Adding $5 \%$ and $10 \%$ of waste to the cement results in strength increase by $15 \%$ and $20 \%$ respectively. With the addition of $30 \%$ of waste the strength of the cement reaches $85.03 \mathrm{MPa}$, which exceeds the strength of the ordinary cement by $23 \%$. The further increase of waste proportion to $40 \%$ and $50 \%$ results in the significant decrease of strength which is connected with the overfeeding of the mineral filler and softening of the composite structure.

The diffractogram of hydrated cement shows that it contains hydrated calcium silicate crystals that are different in both composition and structure. It is also comprised of crystal tobermorite hydrated calcium silicate CSH (I) - d, [angstrom] $=9.8 ; 4.9 ; 3.07 ; 2.85 ; 2.80 ; 2.40 ; 2.00 ; 1.83 ;$ portlandite $\mathrm{Ca}(\mathrm{OH})_{2}-\mathrm{d}$, [angstrom $]=4.93 ; 3.11 ; 2,63 ; 1.93 ; 1.79 ; 1.69$; calcium carbonate $\mathrm{CaCO}_{3}-\mathrm{d}$, [angstrom] $=3.85 ; 3.35 ; 3.04$; $2.49 ; 2.28 ; 2.09 ; 1.93 ; 1.87$.

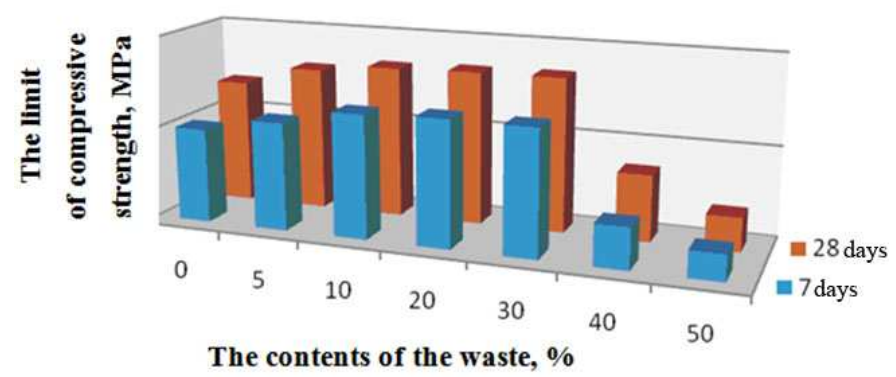

Fig. 10. The dependency between the limit of the compressive strength of the samples and the content of different binding materials in different testing periods 
The diffractograms of hydrated composite binding materials containing from 5 to $30 \%$ of waste indicate the presence of the already stated mineral phases of hydrated cement, as well as diffraction peaks, common to beta-quartz $\mathrm{d}$, [angstrom] $=4.25 ; 3.35 ; 2.45 ; 2.28 ; 2.23 ; 2.12 ; 1.975$; $1.813 ; 1.668 ; 1.656$ and dicalcium ferrite $2 \mathrm{CaO} \cdot \mathrm{Fe}_{2} \mathrm{O}_{3}-\mathrm{d}$. [angstrom] $=7.148 ; 5.242 ; 3.898 ; 3.696 ; 3.056 ; 2.799 ; 2$. 714; $2.68 ; 2.609 ; 2.456 ; 2.356 ; 2.189 ; 2.082 ; 1.949 ; 1.903 ; 1.884$; $1.847 ; 1.746 ; 1.669$.

The increase in waste percentage leads to an increase of beta-quartz amount in compositions. This can be seen when comparing diffractograms of composite binding materials with different compositions.

To confirm the presence of dicalcium ferrite $2 \mathrm{CaO} \cdot \mathrm{Fe}_{2} \mathrm{O}_{3}$ in the composite structure, the surface analysis of hydrated mixed cement samples was done by means of microprobing (Fig.11). The quantitative distribution of elements in the samples of hydrated mixed cements is represented in Table. 4.
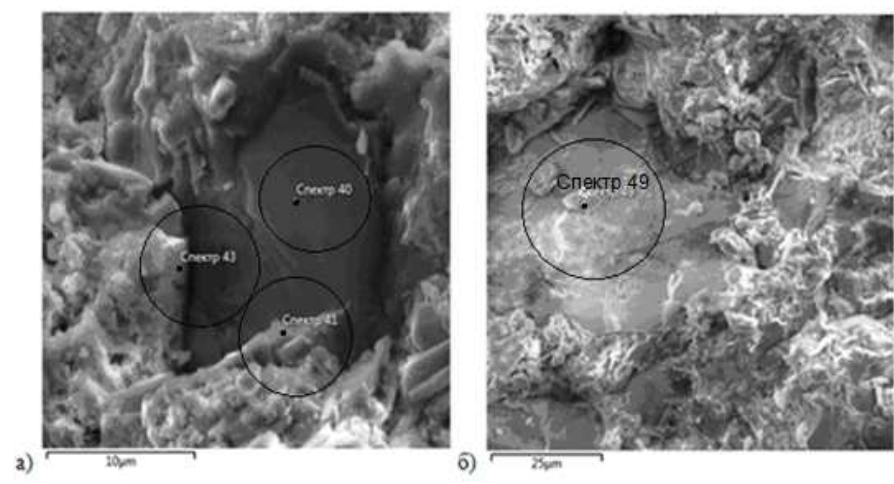

Fig. 11. The photomicrography of chip surfaces of hydrated composite binding material (28 days).

TABLE 4. THE QUANTITATIVE DISTRIBUTION OF ELEMENTS IN THE SAMPLES OF HYDRATED COMPOSITE BINDING MATERIALS

\begin{tabular}{|c|c|c|c|c|c|c|c|c|c|c|c|}
\hline & \multirow[t]{2}{*}{ Number } & \multicolumn{10}{|c|}{ Elements, \% } \\
\hline & & $\mathrm{Fe}$ & $\mathrm{O}$ & $\mathrm{Ca}$ & $\mathrm{Si}$ & $\mathrm{C}$ & $\mathrm{K}$ & $\mathrm{S}$ & $\mathrm{Al}$ & $\mathrm{Mg}$ & $\mathrm{Na}$ \\
\hline \multicolumn{12}{|c|}{ Waste content $10 \%$} \\
\hline \multirow[t]{2}{*}{40} & weight. $\%$ & 27.0 & 36.2 & 1.3 & 15.5 & 12.2 & 5.1 & - & 1.1 & 1.6 & - \\
\hline & [delta]. $\mu \mathrm{m}$ & 1.2 & 0.8 & 0.2 & 0.4 & 0.9 & 0.3 & - & 0.1 & 0.1 & - \\
\hline \multirow[t]{2}{*}{41} & weight. $\%$ & 11.2 & 47.7 & 22.4 & 6.9 & 9.1 & 1.2 & - & 0.6 & 0.4 & 0.5 \\
\hline & [delta]. $\mu \mathrm{m}$ & 1.3 & 0.9 & 0.6 & 0.2 & 0.7 & 0.2 & - & 0.1 & 0.1 & 0.1 \\
\hline \multirow[t]{2}{*}{43} & weight. $\%$ & 8.8 & 26.6 & 53.2 & 3.8 & 6.6 & 1.0 & - & - & - & - \\
\hline & [delta]. $\mu \mathrm{m}$ & 1.4 & 0.8 & 1.1 & 0.2 & 0.6 & 9.2 & - & - & - & - \\
\hline \multicolumn{12}{|c|}{ Waste content $20 \%$} \\
\hline \multirow[t]{2}{*}{49} & weight. $\%$ & 22.4 & 44.3 & 14.8 & 12.3 & - & 3.6 & 0.3 & 0.6 & 1.7 & - \\
\hline & [delta]. $\mu \mathrm{m}$ & 0.7 & 0.4 & 0.2 & 0.2 & - & 0.1 & 0.1 & 0.1 & \begin{tabular}{|l|}
0.1 \\
\end{tabular} & - \\
\hline
\end{tabular}

Spectral analysis shows that point spectrums \# 41, 49 contain calcium ferrites, indicating that combined reduction of cement and waste particles leads to their mechanochemical activation. It is known that processes taking place during the reduction of solid substances are connected with the destruction of natural or artificial minerals. Its intensity is proportional to the amount of mechanical force applied. The development of destruction in crystals leads to the beginning of amorphisation of surface layers with the simultaneous increase in their chemical activity. Uncompensated atomic bonds capable of chemical interaction appear on the surface of dispersion particles during the reduction of minerals. The studies [11] show that a combined reduction of mixture components can result in particular solid-state reactions between particles of solid substances.

The obtained results indicate the mechanochemical activation of mixed cement particles as a result of combined reduction of cement and waste.

The studies of the surface microstructure of hydrated composite binding material samples using TESCAN MIRA 3 LMU scaning-electron microscope showed the differences in their microstructures.

After 28 days of solidification, the cement rock is represented by the thick gel-like mass, consisting of hydrated formations of cement in both amorphous and crystal state with the cores of original crystals of clinker and pores of different size. With significant zooming from $\times 3000$ to $\times 50000$ (Fig.12) it can be seen that the microstructure of a cement rock is represented by separate blocks, consisting of layers formed by flake grains, which in turn consist of small spherical inclusions. The pores of different size and contours are found in the whole mass of material

The analysis of the microstructure of hydrated composite binding materials that solidified for 28 days showed that the formed matrix is quite homogeneous. Hydrated calcium silicates appeared on both filler grains and the bottom layer. Pores and cavities are of insignificant amount.

The denser structure of a composite is formed with an increase of waste amount. This is accompanied by a strongly marked pore occlusion with the formation of thick gel-like mass, containing hydrated cement formations in both amorphous and crystal state with the relict cores of clinker and pores of different size. This is represented in Fig. 12.

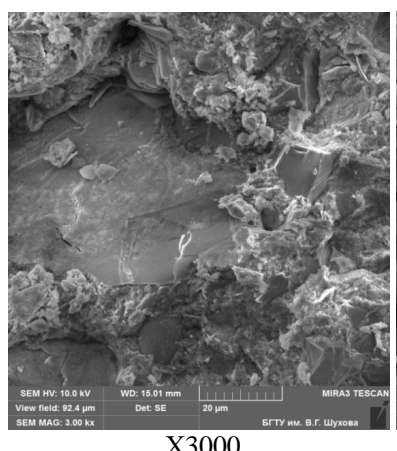

$\mathrm{X} 3000$

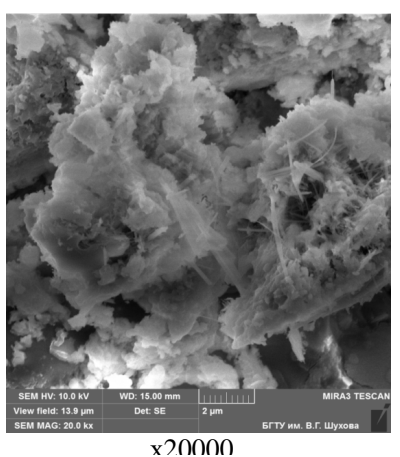

$\mathrm{x} 20000$
Fig. 12. The photomicrography of chip surfaces of hydrated composite binding material with $30 \%$ of waste ( 28 days).

The process of crystallization of new formations results in the partial occlusion of pores and the decrease of rock porosity in general. The porosity decreases with the amount of waste being increased. It can be seen clearly that hydration products 
cover waste particles with different dispersion. The smallest waste grains are the centers of crystallization for new formations which increases the strength of the cement rock.

Thus, the combined reduction of mixture components creates the possibility for solid-state reactions between their particles, which indicates the mechanochemical activation of composite binding material particles.

The study of microstructure in the samples of composite binding materials showed that an increase in the amount of waste leads to the formation of much thicker structure of the material with strongly marked occlusion of pores.

The porosity of samples decreases with an increase in the amount of waste. The waste grains that are equally distributed in the volume of binding materials become the centers of crystallization for new formations, which increases the strength of the cement rock.

This research ascertains the possibility for obtaining composite binding materials with high physical and mechanical properties basing on the beneficiation waste of unoxidized jaspelites. The optimal waste percentage is $30 \%$.

\section{CONCLUSION}

The home-produced FLON and foreign-made PA-14 reagents proved to be the most effective collectors for final tailings of Mikhailovsky mining and processing plant. Hydrolyzed starch was found to be the most active depressor. The recommended concentrations of the floating agent and depressor are 250 gram/ton and 500 gram/ton correspondingly. The rebeneficiation of wet magnetic separation waste containing $32 \%$ of iron and $60 \%$ of silicon resulted in a concentrated product including $61 \%$ of iron and $16 \%$ of silicon expressed as oxide. The concentrate yield is 26 $\%$ of the initial load mass. The work also establishes the procedure for using the waste of iron ore beneficiation by floatation as a mineral filler for the composite binding materials. The use of beneficiation waste of unoxidized jaspelites allows obtaining composite binding materials with high physical and mechanical properties. The usage of industrial material enables one to apply expensive and energyconsuming clinker efficiently. This also solves an important ecological problem of unoxidized jaspelite beneficiation waste recycling that takes large storage space and influences the environment and human health badly.

\section{Acknowledgment}

The article was prepared within a development program of the Base University on the basis of BSTU named after V. G. Shukhov

\section{References}

[1] A.V. Varichev, "From ore recovery to metal production: the evolution of Mikhailovsky mining and processing plant from 2000 to 2010", Mining journal, vol. 7, pp. 6-9, 2006.
[2] V.M. Avdokhin, S.L. Gubin, "Modern state and main trends in advanced benificiation of iron ores", Mining journal, vol. 2, pp. 58-64, 2007.

[3] Yu.S. Spiridonov, "Plant tailing facility: explotation and development", Mining journal, vol. 7, pp. 94-98, 2006.

[4] R.V. Lesovik, "The comprehensive use of tailings of wet magnetic separation of jaspellites", Mining journal, vol. 1, pp. 76-77, 2004.

[5] S.M. Bulatovic, Handbook of Flotation Reagents: Chemistry, Theory and Practice, Flotation of Sulfide Ores, vol. 1. Publisher: Elsevier Science \& Technology Books, 2007, pp: 446.

[6] S.R. Rao, J. Leja, Surface Chemistry of Froth Flotation, 2rd ed., Kluwer Academic Publication: New York, NY, USA, 2004, pp. 388.

[7] N.A. Shapovalov, A.A. Krayniy, A.I. Gorodov, I.S. Makuschenko, “ Study of the influence of different kinds of collectors and depressant flotation iron-containing minerals mikhailovsky deposit", Fundamental research, vol. 9, pp. 318-323, 2014.

[8] N.A. Shapovalov, L.K. Zagorodnyuk, I.V. Tikunova, A.Y. Schekina, "Rational way to use steel slag", Fundamental research, vol. 1, pp. 439443, 2013.

[9] E.G. Avakumov, The mechanical methods of chemical processes activation, Novosibirsk: Science, 1986, pp. 304.

[10] V.V. Boldirev, Experimental methods in mechanochemistry of mineral substances, Novosibirsk: Science, 1983, pp: 65.

[11] V.N. Mochalov, V.G. Selezneva, E.N. Zhirnov, The activation of minerals during reduction, Moscow.: Nedra, 1988, pp. 208.

[12] V.I. Silaev, A.F. Zaboev, V.I. Ilovayskiy, L.A. Khoroshilova, "Phase transformation of some sulphides when heated", Collected papers of Komi Institute of Geology, vol 23, pp. 94-98, 1977. 